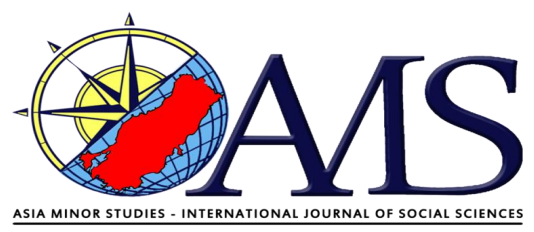

Cilt: 6, Sayı: AGP Özel SayıSI, Ekim 2018 / Volume: 6, Issue: AGP Special Issue , October 2018

\title{
AN EVALUATION ON HISTORY-MEMOIRS RELATIONSHIP IN ACADEMIC HISTORY STUDIES ${ }^{1}$
}

Akademik Tarih Araştırmalarında Tarih-Hatıra İlişskisi Üzerine Bir Değerlendirme

Olcay ÖZKAYA DUMAN*

\section{ÖZ}

Tarihe tanık ve tarihin belli bir dönemine adanmış olma, kişilerin geçmişten biriktirerek getirdikleri hatıralarından, tanıklık etmiş oldukları yaşadıklarından edindikleri bilgileri gelecek kuşaklara aktarılabildikleriyle mümkündür. $\mathrm{Bu}$ anlamda hatıra veya anılar tarih yazımının önemli referansları arasında yer almaktadır. $\mathrm{Bu}$ konuda tarihin temel kaynaklarını ele alan referanslar üzerine önemli çalışmalar mevcuttur. Tarih, bu yönüyle kendi kaynaklarını tartışarak yöntem bilim üzerine yeni bakış açıları ortaya koymuştur. Anı ve Hatıratın Tarih ile ilişkisi üzerine farklı bakış açıları bulunmaktadır. Bunlardan birine göre anılar gelecekte varlığını sürdürmek isteyen bireyin, özel veya toplumsal yaşantısının bir kesitini kamuya meletmesidir. Anıların yazılma nedenleri arasında, unutulmamak, kaybolmasından korkulan bir gerçeği tarihe, topluma aktarmak, birlikte yaşadığı kişilere hayranlığını bildirmek, bir tür günah çıkartmak, gelecek kuşaklara ders vermek yer almaktadır. Anı yazılarında yazarların ana kaygısı, kendilerini değil yaşadıklarını anlatmaktır. Buna göre kişi anlatılarını tarihe teslim ederek onun önemli bir referansı olur.

Söz konusu çalışma akademik tarih araştırmalarının ana referansları olarak değerlendirilen Hatıratların, bu türden çalışmalara katkısını ortaya koymak, anı anlatılarının metodolojik kullanımı ve yazımı hakkında bir analiz yapmayı amaçlamaktadır. Bu şekilde akademik tarih çalışmalarında olayların belgelerde görünmeyen öteki yüzü, aynada görülmeyen diğer yarısı, insanı ortaya çıkaran ve gündelik yaşama dair ayrıntılar ortaya çıkarılarak olay ve olguların çeşitli açılardan değerlendirilmesine olanak sağlanmış olunacaktır. Bu durum hatırat türünden kaynakların tarih çalışmalarına katkıları olarak değerlendirilmelidir.

Anahtar Kelimeler: Tarih, Hatırat, Sosyal Bilimler, Olay ve Olgu.

\footnotetext{
${ }^{1}$ This article is based on a paper presented at the 12th AGP International Humanities and Social Sciences Conference (4-6 May 2018 Charles University, PRAGUE) Prague, Czech Republic.

* Asst.Prof.Dr. in Department History of Turkish Republic , Mustafa Kemal University, Turkey. (ozkaya@mku.edu.tr.)
} 


\begin{abstract}
Witnessing history and feeling dedicated to a certain period of history can be possible if people pass on their knowledge which they've obtained from their memories and past experiences to the next generation. With this regard memories are among the most significant references while writing history. There are important studies that discuss the references which approach the main sources of the history. History puts forward new perspectives on methodology by discussing its own sources. There are different views on the relationship between memoirs and history. According to one of these views memoirs can be defined as the act of publicizing part of a private or social life by an individual who wants to continue his/her existence in the future. The reasons why memoirs are written can be stated as to prevent memories from being forgotten, passing on a reality (that is afraid to be lost) to history, society, to show your admiration to people you live with, to confess a sin or to give a lesson to next generations. The main concern of the authors in writing memoirs is writing about their experiences instead of writing about themselves. By this the person devotes his/her narration to history and becomes a significant reference of it.

The relevant study aims to put forward the contribution of memoirs to the history studies and analyze the methodological usage and writing process of the memoirs which are regarded as the main references of academic researches on history. In this way an opportunity will be provided to evaluate the events and facts from different perspectives by revealing the invisible parts of the events which can't be found in the documents, the other side that can't be seen in the mirror, the details which reveal humanity and daily life. This situation should be interpreted as the contribution of memoir source type to history studies.
\end{abstract}

Keywords: History, Memoirs, Social Sciences, Events and Facts.

\title{
INTRODUCTION
}

An important subject which is taken into consideration in the methodological issue of the history research is the position of memoirs and how these memoirs should be evaluated and analyzed. It will be suitable to shortly touch upon the method in history before approaching the subject directly. There are very few studies in Turkey about the method issue in history in other words about the understanding and comprehension of historical events. While the subject is generally discussed superficially it is also trapped in the introduction parts of few history books and newspaper articles. It is discussed based on two opinions not only in Turkey but also outside Turkey. On one hand it is argued that it can be examined just as a natural science and there can also be a causal law in history on the other hand history is considered as historiography (chronicler) and a historian as a recording device. In general, historical events which are the subject unit of history can't be completely comprehended by strict deductive and inductive methods of physical and natural science. Because the accuracy of the subjects which these sciences are interested in can be proved by experiments. But in history the experiments are not conducted in the way understood by the physician. The method 
considerably used in history is the reduction method. There are no probabilities in history, probability pertains to physical and natural science. The subject unit of history is unique. The subject unit of history is first of all a historical event, cause or causes of this events in other words the interpretation of the event(Sander,1976:183184). When considered within the framework of methodology these events are important in various ways as they leave marks on the lives of human beings (the main references of history) and in turn the society. All of these significant events are hidden in the memoirs which are experienced and put down on paper by people over time. Memoirs are valuable works with regard to the fact that they shed light on the events of the period.

Memoir or remembrance arises from people's desire to share their life and experiences with other people and also from the fear of being forgotten and to come to terms with history. With the desire to share, the memoir writer expresses the past by reviving the traces that are left by the events on his/her mind. Although memoir is new as a literary genre it can be encountered in anecdotes with political and historical features and in ancient writings. Among these are Caesar's Gallic War, Baburnama of Zahīr-ud-Dīn Muhammad Bābur etc. It's not easy to draw certain borders and make various definitions about the memoirs according to these borders. Steinberg defined memoir which had its first examples as a special genre in the XVI. century from the European Literature and became widespread with the influence of XIX. century romantics as "the texts written by people for his/her private or social life". In the East, memories were present in works which were written in different genres such as biography collections, travel journals, legends(Akar, 2004:383).

According to another point of view it is stated that in order to evaluate all of the autobiographic writing types in the West from XIV. Century onwards-which can be defined as the story of being an individual-and also memoirs in particular within the scope of this definition in the Ottoman Empire which had an isolated society and also part the ways of these two concepts with history, XIX. century should be awaited. In this century in which under the influence of Western civilization modernization of Ottoman Empire were laid, apart from or besides individualisation and the concept of us(criterions for modernization) the existence of 'I' was also questioned. During the recent years studies conducted both in the field of Literature and History indicate that intellectuals of the Ottoman period left some records regarding their lives in fact these studies also indicate that these texts date back to the old times of the Westernization period. However the important points to consider in this situation, first and foremost, are the aim of these personal narrations and the behavior of the people in terms of being themselves or in order words presenting their own world while putting down these texts on paper (Öztürk, 2011:305).

New view points and different studies on memoir writing and narration were supported by type of works which could contribute to the improvement of history works. From this point of view especially early 21 st century draws attention as it's the period in which these types of studies were conducted and works were written. The studies of Georg G.Iggers can be given as an example for these relevant works. Most of the part of Iggers' work consists of Lawrence Stone's article named 


\section{$\underline{\text { An Evaluation On History-Memoirs Relationship In Academic History Studies }}$}

"The Revival of Narrative: Reflections on a New Old History". This article emphasizes a basic transformation in viewing and writing style of history which emerged during 1970's. ${ }^{2}$ It can be understood that this emphasis on the concrete experiences of people aims to present different point of view to the expressive types of history (Iggers, 2000:99).

Memory and memoirs were first used by(s.369) Muallim Naci (1850-1893) in the sense of the present day and later on memoir became the name of this genre. Memoirs are works written on a particular idea that comes to mind, a matter that is remembered, a circumstance, situation, hatıra-1 ahd-i şebab (memories which are loyal to past), memoirs of the society. Memoir is determination of the traces of life experience and impressions and in that way it's very different from a diary (agenda). If a diary is the identification and a photograph of the day then memoirs are the photographs of the whole life or part of the life which are taken subsequently from the traces of the person's mind. In other words a person as a memoir writer is his/her own historiographer (Birinci, 1998:611).

As memoir writing became common as a completely independent genre in the Western Literature especially from XIX. century onwards a search for an Arabic and Turkish word for the term began. In Arabic müzekkirat and zikrayat and in Turkish the word hatıra which also had and Arabic origin but a different meaning was used for the word memoire. The use of hatırat (memoirs) as the plural of hatira (memory) began during the beginning of this century (Akar, 2004:384). ${ }^{3}$ Even though the word memoire in French is used as hattra in Turkish the meaning is different from the meaning which combines memoir and memory. In XIX. century memoir became popular as an independent genre in modern understanding. Based on its meaning in French it was defined as things that are memorable (Öztürk, 2011:305). ${ }^{4}$

Within the framework of the understanding advocating pure Turkish language the word an $\iota$ which is the word used today for this genre that is among the important references of history substituted for the word hatıra. Even though this genre which developed in the XIX. century became more widespread after the

\footnotetext{
${ }^{2}$ For detailed information on social memory see:. Paul Connerton, How Societies Remember, Transl.:Alaeddin Şenel, Ayrıntı Publications, 1999, İstanbul and İlber Ortaylı, Journey to the Borders of History (Tarihin Sinırlarına Yolculuk), Timaş Publications, İstanbul, 2007.

${ }^{3}$ For detailed information on this subject see: Orhan Okay, "Memoir", Islamic Encyclopedia, Religious Foundation Publications, C.16, İstanbul, 1997 and Robert R.Rchıbald, “ A Personal History of Memory", Social Memory and History, Edited by Jacob J.Climo and Maria G.Cattell, Altamira Press, New York, 2007 ve Paul Thompson, Voice of the Past, Tarih Vakfi Yurt Yayınları (Publisher), İstanbul, 1999 which considers the relationship between Hisory and Memoir in a methdological framework and gives detailed informaton within this scope.

${ }^{4}$ For detailed information on conceptual definitions see:. Banu Altınova, "Memoir" as a Literary Genre within the Framework of Contradicting Concepts ("Kavram Kargaşası Çerçevesinde Edebi Bir Tür Olarak "Hatıra"), Türkbilig, 2003/6, Page 3-12 ve Z.Velidi Togan, Method in History (Tarihte Usûl), İstanbul University Faculty of Letters Publications, İstanbul, 1950.
} 
modernization period-in which the first examples of new ideas and concepts were seen- and promoted, became a source for other type of works, the works of the memoir/memory type are relatively few. Although numerous writers tried to explain this deficiency via various reasons it's an important, challenging, remarkable issue that this genre which gradually boomed isn't basically embedded in our literature. In order to put forward the validity of the memory genre the statement made by A.Davenport is rather important; "There are no people in England of certain age that haven't written a memoir”'(Karakoç, 2008:377).

Just like in other parts of life the evolving process established by modernization especially in the world of dreams directed people to understand, predict, discuss, record, save, transfer and share the course of events and facts around them. It can be stated that this process became more notable from 1908 onwards by increasing in low frequency as the literary genres of the period produced works which were rich in terms of memoirs. The fact that this genre evolved as a literary memoir instead of historical is remarkable. This determination can be understood when the quality and the number of the works of the period are analyzed. The habit of writing a memoir increased over time as the tendency of firstly figures that are prominent in the society in various ways and then other individuals can be clearly observed. Memories/Memoirs might have been written due to numerous reasons. Our curiosity on this subject can be satisfied by analyzing these type of works. Among these reasons the following can be stated; saving and sharing the important information concerning a certain period, event, fact, ensuring the transfer of these to the next generations, feeling concerned about the fact that these type of information can be lost, desire to advise and give recommendations. In addition to this reasons such as revealing the effect of events on time and also the effect of time on events, foregrounding the individual and the event, transferring heroism by narrations, transferring feelings like fear, excitement etc. that witness the evolving process of events but are rarely found in other documents.

In order to understand the relationship between history and memoirs Fatma Aliye Hanım is a good example. According to Fatma Aliye (1862-1936)-also to other memoir writers of the period- memoirs are "life histories". During the relevant period even though these definitions weren't present in their works most of them mention about memoirs as life histories (in other words biographies). Life histories acquire a different dimension in history. Historical events are the interpretation of events and individuals. In Fatma Aliye's book Ahmet Cevdet Pasha and His Time which is about the memoir of her father biography is used as the synonym of life history. Within the scope of this equivalent usage she emphasizes the opportunity of the life history writers in terms of taking part in the history within the scope of this emphasis private life is considered separately. The separation of private life and the saying that only her father can write his own life are important for memoirs. Within this scope private life is equivalent to memory. In her book Fatma Aliye also considers memoir as "a way of writing historical events". She lays emphasizes on the fact that while transferring historical cases the things written should be accurate. Thus she puts forward the relationship between history and memoir (Öztürk, 2011:314). 
Memoir is not the story of a personal life. Beyond the person it is the narration of everything that happens around the person. In that way memoirs are sources which present historical periods and events in various ways. It should be stated that this genre became common from the beginning of the XX. century. Kütükoğlu stated that the importance given to memoirs increased from XIX. century onwards. Kütükoğlu also stated that important people like Sultan Abdülhamit II., Mithat, Said, Kamil Pasha and member of Committee of Union and Progress Ibrahim Temo also put down their memories on paper(Kütükoğlu, 2011:24).

There are many examples of memory writing. The Great Speech (Nutuk) which describes Turkish War of Independence in detail and written by Mustafa Kemal Atatürk is one of the most important examples of memoirs in Turkish Literature. There are also memoirs written by important commanders like Kazım Karabekir (Why Did We Enter The World War?, How Did We Enter The World War, How Did We Manage The World War?/Cihan Harbine Neden Girdik. Nasıl Girdik, Nasıl İdare Ettik?), Ali Fuat Cebesoy (War of Independence Memoirs/Milli Mücadele Hatıraları), İsmet İnönü (Memoirs/Hatıralar). These types of memoirs constitute the sources of the history writing of the recent periods in Turkey which require sensitivity. In fact apart from archive, periodicals and books these type of texts constitute the fourth group of sources in researches which are conducted on the last century. Especially letters and documents in the memoirs increase the reliability of these works and provide a worthwhile evidence for history researches(Demirtaş, 2017:167). ${ }^{5}$ With regard to the way the past narrations interpret present time for the experienced historical events Bloch emphasizes the vibrations of human life and a process which can be perceived via our emotions. According to him without experiencing in person would it be possible to understand the confusion of an army due to a siege or the confusion of a community due to a defeat? The experiences of people put forward the feeling of being lost and the failing process of the societal structures with regard to our daily experiences (Bloch, 1985:28). ${ }^{6}$

According to Birinci the main development of the memoir was after the proclamation of constitutional monarchy. According to him memoir writers can be separated into groups. Among these are writers, actors, actresses, journalists, people that are in close relation with the palace, ulemas, sheikhs, teachers, scientists, foreigners, people in captivity, businessmen, soldiers, lawyers, administrators, police

\footnotetext{
${ }^{5}$ For more information on Social Science Disciplines see.: Gulbenk1an Komisyonu, "Sosyal Bilimleri Açın", Metis Publications, İstanbul, 1996. There are many works written on memoirs which are about various periods. Among these are works of Second Constitutional era. For more information on these works see.: Murat Hanilçe, An Essay on the Bibliography of Memoirs on The Second Constitutional Era ("İkinci Meşrutiyet Dönemine Dair Hatırat Bibliyografyası Denemesi"), Bilig, Fall/2008, Number 47, Page 147-166.

${ }^{6}$ For more information on narrations and criticism of other sources in history researches see.: Leon E. Halkin, Factors of Historical Criticism (Tarih Tenkidinin Unsurlarl), Transl.: Bahaeddin Yediyıldız, Turkish History Institution publications, Ankara, 1989 and İsmail Özçelik, Methods and Techniques in History Researches (Tarih Araştırmalarında Yöntem ve Teknikler), Nobel Akademik Publications, Ankara, 2012.
} 
officers and people from other professions. Recently it attracts attention that in particular people who are members of Foreign affairs of the Republican Period, female writers, scientists write and publish their own memoirs(Birinci, 1998:615).

In addition to the memoir works stated above there are many works which were written in different periods. Among these are the book named Turkish Independence War which was published in 1973 and written by Fahri Belen who was a division commander during the War of Independence and later on became a lieutenant general and the book named "Ten Year War and Afterwards 1912-1922 which was written by Fahrettin Altay who was successful against the enemies during The Great Raid and the first commanding officer to arrive in Izmir. Apart from these works the following books of Rahmi Apak are important works of the period; How was Western Front Established in the War of Independence (1949) and Memoirs of Seventy Year-old Officer (1957). The work of İzzettin Çalışlar named Memoir of War of Independence which consist of five volumes can be considered within these type of works. Mustafa Kemal Atatürk being in the first place İsmet İnönü, Ali Fuat Cebesoy, Asım Gündüz, Kazım Özalp, Salih Bozok who joined the war in person or witnessed it also wrote down their memories about the period (Altıkulaç and Yeşilbursa, 2014:163).

According to Birinci apart from archive, periodicals and books these type of texts constitute a fourth source group fort the history researches of the last century. In a history research these four groups should be evaluated in minimum standards. In fact memoirs are essential components of the first three group. In these type of texts both information regarding human and other types of information which are not stated in other texts can be found. In Political history or intellectual history we can see these sources as completely essential and primary sources. These kind of sources can compensate for the monotony in official documents and sources. Due to this apart from stating the name of the memoir historians should also analyze the content of it. One must pay attention if the memoirs are based on reality, simplified or chosen. Memoirs should be considered within the framework of the subject that is discussed. It is also important to collect and present statements from various memoirs on the same subject and to compile various statements. In other words it is important to fulfill the "listen to the other side" (Audi alteram partem) condition of history. Birinci remarked that by using this working method memoirs which can be regarded as historical sources can be promoted from individuals' history to societies' history by giving importance to the rules of history(Birinci, 1998:618-619).

When considered in general with all of the examples, people who see what other people do and identify them correctly, take their photographs or people who write memories of their experiences correctly present significant documentaries for history. But as the understanding of people who observe vary depending on abilities and moral status, the observer's provisions on these events are generally different and in noncompliance with each other. Brundage who considers memoirs in the category of sources published from primary history sources states that even if they includes comments in the favor of the writer or serve for aim of the writer these type 


\section{$\underline{\text { An Evaluation On History-Memoirs Relationship In Academic History Studies }}$}

of sources are by no means insignificant as apart from other features memoirs present valuable information on the personality of prominent people. With regard to the historical value of memoirs information can be provided from the Annales 7 movement which left marks on the $20^{\text {th }}$ century historiography. Leopold Von Ranke and his contemporaries who were the pioneers of the movement advocated that instead of focusing on policy a history paradigm should focus on historical events which completely approach human events. (Altıkulaç and Yeşilbursa, 2014:162). ${ }^{8}$

Discussions based on the modernization of history in the 20th century were approached by numerous works written on history and history method. An important work among these is the "Re-thinking History" written by Keith Jenkins. This work which was translated by Bahadır Sina Şener started discussions on the content of history and History in the Postmodern World. Anglo-centered, Europe-centered, etno centered, sex-centered, reason-centered approaches were also among the subjects which were opened up for discussion. As required by the skeptical and critical approach history moved away from minimal theme definitions and was considered in a re-interpretation process. At this part discussions put forward on history and narration in history writing have an extensive coverage (Jenkins, 1997:71). ${ }^{9}$ The subjected discussions are very important to understand the significance and essentialness of memoirs in history works.

Generally in academic history works in which memoirs are regarded as important references, memoirs can provide valuable information and findings that

\footnotetext{
${ }^{7}$ The most innovative, unforgettable and important works of history of the $21^{\text {st }}$ century was produced in France.

From time to time it was a famous and discussed subject just as La nouvelle histoire (new history), la nouvelle cuisine (new cuisine). Most parts of this new history consists of the works of a group which was established in 1929 and comes to mind via the journal named Annales. People who aren't among the group emphasize the common points of this work and recall the writers of these works by the name of Annales School. On the other hand people who are among the group emphasize personal differences and state that such a group doesn't exist. Lucien Febvre, Marc Bloch, Fernand Braudel, Georges Duby, Jacques Le Goff and Emmanuel Le Roy Ladurie are the prominent figures of the group. Peter Burke, French Historical Revolution: Annales School, Transl.: Mehmet Küçük, Doğu-Batı Publications, Ankara, 2002, p.23-24. Furthermore for detailed information on Annales School, histogriography events within the scope of this school, texts of Bloch, Febvre and Braudel (founders of the school) see.: Burke, Bloch, Febvre v.d., History and Historian on the Path of Annales School(Tarih ve Tarihçi Annales Okulu İzinde), Der.:Ali Boratav, Kırmızı Publications, İstanbul, 2007.

${ }^{8}$ For detailed information about this subject see: R.G. Collıngwood, Tarih Tasarımı, Çev.: Kurtuluş Dinçer, Ara Publications, İstanbul, 1990 and M.Buhr; W.Schroeder; K.Barck, The Philosophy of Enlightenment,Transl.: Veysel Atayman, Yenihayat Publications, İstanbul, 2006.

${ }^{9}$ For detailed information on 20th century history writing and historiography see: Georg G.Iggers, Historiography in the Twentieth Century: From Scientific Objectivity to Postmodern Challenge, Tarih Vakfı Yurt Yayınları(Publisher), İstanbul, 2000 ve E. Bernheim, Introducton to the Historical Science, Method and Philosophy of History, Transl.:M.Şükrü Akkaya, Ministry of Culture Publications, İstanbul, 1936.
} 


\section{$\underline{\text { An Evaluation On History-Memoirs Relationship In Academic History Studies }}$}

will enlighten different directions of history if they are taken into consideration by comparing and analyzing them with each other and other works. As mentioned by Kütükoğlu it's not possible to write memoirs objectively as they are put down on paper by prioritizing feelings and personal opinions. Thus these works should be used after comparing them with other works in other words after criticism. (Kütükoğlu, 2011:25). Within this point of view the invisible side of the events which is the human side is revealed. This situation serves as lifeline water that provides a chance to perceive the events from various aspects with a broader perspective.

\section{CONCLUSION}

Works which are put down own paper by people that shed light on various periods of history, witnessed the process and the improvement in a way or received the information from the first-person are not merely of the biography type. These works can include significant information which can shed light on each type of improvement of the period. In this way memoirs which can be regarded as these type of works should be considered as primary references for history researches. In the work "Tarih Araştırmalarında Usûl" (Method in History Research) written by Kütükoğlu it is stated that "works which are of memoir type have a value as they shed light on the events of the period... but these shouldn't be used without criticism”.

Memoirs are rich works in terms of presenting details which in a way affected the development of historical events that weren't stated in archive documents, periodicals and other sources. The works which are written by memoir writers about their personal feelings, thoughts and because of their intention to reflect their ideology are dependent to be criticized. This weakness of memoirs significantly reveals the need to compare the memoirs of the period both among each other and both with other written or various types of sources.

Within the scope of this approach as a final say memoirs as a source type can carry the academic history research further than archive and document historiography. This situation can be regarded as an effort which can carry scientific researches conducted in this sense further and see and understand the the events from different perspectives in a broader sense. Such that a historian will receive a chance to reveal the heroes that are left in the dark rooms of the history or the heroes who haven't been seen and noticed. The historian will also receive a chance to reach the information which in a way direct the flow and development of the history. 


\section{REFERENCES}

Akar, Ş. K- İrfan Karakoç (2004). "Siyasi Tarih Kaynağı Olarak Hatırat ve Gezi Notları”, Türkiye Araştırmaları Literatür Dergisi, C.2, S.1, ss 383-421.

Altınova, B. (2003). "Kavram Kargaşası Çerçevesinde Edebi Bir Tür Olarak "Hatıra", Türkbilig, Sayfa Aralığı 3-12.

Altıkulaç, A- Emine Güntepe Yeşilbursa (2014). "Tarih Araştırmacılarına Göre Hatıratların Tarihsel Değeri”, ISHE.

Bernheim E. (1936). Tarih Ilmine Giriş, Tarih Metodu ve Felsefesi, Çev.:M.Şükrü Akkaya, İstanbul: Kültür Bakanlığı Yayınları.

Birinci, A. (1998). "Hatırat Türünden Kaynakların Tarihi Araştırmalardaki Yeri ve Değeri”, Atatürk Araştırma Merkezi Dergisi, Sayı: 41.

Bloch, M. (1985). Tarih Savunusu Ya Da Tarihçilik Meselesi, Çev.: Mehmet Ali Kılıçbay, Ankara: Birey ve Toplum Yayınları.

Burke, P. (2002). Fransız Tarih Devrimi: Annales Okulu, Çev.: Mehmet Küçük, Ankara: Doğu-Batı Yayınları.

Burke, B- Febvre v.d. (2007). Tarih ve Tarihçi Annales Okulu İzinde, Der.:Ali Boratav, Kırmızı Yayınları, İstanbul.

Collıngwood, R.G. (1990). Tarih Tasarımı, Çev.: Kurtuluş Dinçer, Ara Yayınları, İstanbul.

Buhr, M- W Schroeder- K Barck (2006). Aydınlanma Felsefesi, Çev.: Veysel Atayman, İstanbul: Yenihayat Yayınları.

Connerton, p.(1999). Toplumlar Nasıl Anımsar, Çev.:Alaeddin Şenel, İstanbul: Ayrıntı Yayınları.

Çukurova, B. (1999). "Milli Mücadele Anıları Üzerine Bir Bibliyografya Denemesi 1”, Ankara Üniversitesi Türk İnklâp Tarihi Enstitüsü Atatürk Yolu Dergisi, $\mathrm{VI} / 23$.

Demirtaş, B. (2017). "Tarih Yazımında Hatırat ve Günlüklerin Yeri ve I.Dünya Savaşında Kafkas Cephesi Örneği”, Tarih ve Gelecek Dergisi, C.3, Sayı 1.

Gulbenkıan Komisyonu. (1996). Sosyal Bilimleri Açın, İstanbul: Metis Yayınları.

Halkın, L. E. (1989). Tarih Tenkidinin Unsurları, Çev.: Bahaeddin Yediyıldız, Ankara: Türk Tarih Kurumu Yayınları.

Hanilçe, M. (2008). “İkinci Meşrutiyet Dönemine Dair Hatırat Bibliyografyası Denemesi”, Bilig, Güz/2008, Sayı 47, Sayfa Aralığı147-166.

Iggers, G.G. (2000). Bilimsel Nesnellikten Postmodernizme Yirminci Yüzyılda Tarihyazımı, İstanbul: Tarih Vakfı Yurt Yayınları. 
Jenkins, K. (1997). Tarihi Yeniden Düşünmek, Çev.. Bahadır Sina Şener, Ankara: Dost Yayınları.

Karakoç, İ. (2008). "Edebiyat Tarihi Kaynaklarından Hatıralar ve Osmanlı'dan Günümüze Edebiyat Hatıraları Bibliyografyası Üzerine Bir Deneme", Kebikeç, Sayı 26, Ankara: Kebikeç Yayınları.

Kütükoğlu, M. (2011). Tarih Araştırmalarında Usül, II.Dizi, Sayı 6, Ankara: Türk Tarih Kurumu Yayınları.

Okay, O. (1997). "Hatırat", İslam Ansiklopedisi, C.16, İstanbul: Diyanet Vakfı Yayınları.

Ortaylı, İ. (2007). Tarihin Sınırlarına Yolculuk, İstanbul: Timaş Yayınları.

Özçelik, İ. (2012). Tarih Araştırmalarında Yöntem ve Teknikler, Ankara: Nobel Akademik Yayıncılık.

Öztürk, B. (2011). “Tanzimat Yazarlarına Göre Hatırat Türü”, TÜBAR, XXIX.

Rchibald, Robert R. (2007). “ A Personal History of Memory”, Social Memory and History, Edited by Jacob J.Climo and Maria G.Cattell, New York: Altamira Press.

Sander, O. (1976). “Tarihte Yöntem”, Toplum Bilimlerinde Araştırma ve Yöntem, Derleyen:Ruşen Keleş, Türkiye ve Orta Doğu Amme İdaresi Enstitüsü Yayınları, No.152, Sayfa Aralığı 183-197, Ankara: Sevinç Matbaası.

Thompson, P. (1999). Geçmişin Sesi, İstanbul: Tarih Vakfı Yurt Yayınları.

Togan, Z.V. (1950). Tarihte Usûl, İstanbul: İstanbul Üniversitesi Edebiyat Fakültesi Yayınları. 